\title{
2016 年度論文校閲者へのお礼
}

日本応用動物昆虫学会誌 (60 巻) および Applied Entomology and Zoology（Vol. 51）の編集に際し，論文校閲者として下記の方々のご 協力を得ました. 厚くお礼申し上げます。

\section{和文誌 $(60$ 巻 $)$}

\begin{tabular}{|c|c|c|c|c|c|c|c|c|c|c|}
\hline 智佐 & 有村源一郎 & 羽田 & 厚 & 星野 & 滋 & 星崎 杉彦 & 井上 & 広光 & 石島 & 力 \\
\hline 陰山 大輔 & 梶村 恒 & 柿元 & 一樹 & 河合 & 章 & 工藤 & 國本 & 佳範 & 増井 & 伸一 \\
\hline 敏治 & 水谷 & 森山 & 実 & 本林 & 隆 & 村上 & 中 & 秀司 & 西野 & 実 \\
\hline 伸也 & 太田 & 大友 & 令史 & 奥 & 圭子 & 長田 庸平 & 尾崎 & 研一 & 齊藤 & 美樹 \\
\hline 充隆 & 佐藤 & 世古 & 智一 & 清水 & 健 & 塩尻かおり & 末吉 & 昌宏 & 田㴊 & \\
\hline 明彦 & 裕之 & 竹内 & 博昭 & 滝 & 久智 & 土田 聡 & 杖田 & 浩二 & 和田 & \\
\hline 伸夫 & 山崎 廉予 & 吉田 & 智弘 & & & & & & & \\
\hline
\end{tabular}

\section{英文誌 (51 巻)}

\begin{tabular}{|c|c|c|c|c|c|c|}
\hline 安部 & 安部順一朗 & 秋月 & 秋元＼cjkstart信一 & 秋野＼cjkstart順治 & 青木 智佐 & 新井＼cjkstart朋徳 \\
\hline 新川 & 有村源一郎 & Armstrong, Karen & 浅野眞一郎 & Atlihan, Remzi & 馬場 友希 & Bervillé, André \\
\hline Breeuwer, Hans & Buchmann, Stephen & & Chen, Yan & Chi, Hsin & 泰行 & Cornette, Richard \\
\hline Cowie, Robert & 遠藤＼cjkstart信幸 & 遠藤 & 藤家 梓 & 辻井 直 & 深野 & 舟山＼cjkstart健 ～ \\
\hline 古川 誠一 & 二橋 亮 & Giordano, Rosanna & & 後藤 千枝 & 後藤 & Guncan, Ali \\
\hline Gusev, Oleg & 羽田厚 & 原野＼cjkstart健一 & 知幸 & 畠山 吉則 & 服部 & Haynes, Kyle \\
\hline Hilario, Sergio Dias & & 日室 & 日本 典秀 & 平山 & Hodek, Ivo & 北條＜wide>賢 \\
\hline 堀＼cjkstart雅敏 & 星崎＼cjkstart杉彦 & 細石 & 細川 貴弘 & 一木 良子 & 井出 純哉 & 池本 孝哉 \\
\hline 今井 利宏 & 井上 広光 & 井上 & 石橋純 & 石田＼cjkstart裕幸 & 石島 & 石川 \\
\hline 石本万寿広 & 磯野 昌弘 & 糸山 & 岩淵喜久男 & 岩堀 英晶 & 岩泉 & 将司 \\
\hline 岩田隆太郎 & Jalali, Amir & 神保 & Jordaens, Kurt & 門野＼cjkstart敬子 & 陰山 & 洋一 \\
\hline 梶村 恒 & 柿元 一樹 & 神村＼cjkstart学 & 神崎＼cjkstart菜摘 & 笠井 & 葛西＼cjkstart真治 & 加進 \\
\hline 川北 & 粥川 环巳 & Kezic, Nikola & 菊池 義智 & 菊田 真吾 & Kim, Hyojoong & 木村 \\
\hline 岸本 英成 & 岸本 年郎 & 駒形＜wide>修 & 今野浩太郎 & 小坂＼cjkstart肇 & 小滝＼cjkstart豊美 & 健雄 \\
\hline 釘宮＼cjkstart聡一 & 栗和田 隆 & Kutcherov, Dmitry & & Leblanc, Luc & Lecocq, Thomas & Lee, Joon-Ho \\
\hline Lesieur, Vincent & Li, Houhun & Lin, Tong & Liu, Tong-Xian & Lowe, Graeme & 前田太郎 & 前原＼cjkstart紀敏 \\
\hline 前野浩太郎 & 牧野 俊一 & 牧野＼cjkstart崇司 & 松田一彦 & 松倉啓一郎 & 松本由記子 & 松村 正践 \\
\hline 松尾 和典 & 松尾 隆嗣 & 松山 & McCarty-Glenn, & & 水口智江可 & 三田＼cjkstart敏治 \\
\hline 三橋 渡 & 光永 貴之 & 三浦 & 宮本＼cjkstart和久 & 水谷 信夫 & 森下 正彦 & 務川 \\
\hline 村井 & Musolin, Dmitry & 長坂 幸吉 & 中秀司 & 仲井まどか & 中森 & 中野 \\
\hline 義貴 & 夏原由博 & Nekola, Jeff & 惠子 & Nishanth Kumar, S & 西田 & 西田 \\
\hline 雄大 & 野田 博明 & 野下＼cjkstart浩二 & 野村 昌史 & 野村＼cjkstart周平 & 沼田 英治 & 伸也 \\
\hline 大西 & 大野 & 太田 & 大井田＼cjkstart寛 & 岡部貴美子 & 岡田 浩明 & 大村＼cjkstart尚 \\
\hline 大澤＼cjkstart剛士 & 克久 & 尾崎 & Park, Kyu-Tek & Patt, Joseph M. & Pereira, José & Robson, Simon \\
\hline Roskam, Johannes & 齊藤 & 齊藤 & 榊原＼cjkstart充隆 & 坂巻＼cjkstart祥孝 & 佐々木哲彦 & 佐藤＼cjkstart安志 \\
\hline 世古＼cjkstart智一 & 瀬尾＼cjkstart茂美 & 柴尾＼cjkstart学 & 篠田 徹郎 & 塩尻かおり & 塩月 孝博 & 白石 昭彦 \\
\hline \multicolumn{2}{|c|}{ Shivashankar, Seshadri } & Simon, Chris & 曽根＼cjkstart晃一 & 園田＼cjkstart昌司 & 末次 & 杉浦 \\
\hline 鈴木＼cjkstart芳人 & 田端 & 田㴊＼cjkstart研 & 多田内 修 & 高林 純示 & 高木 悦郎 & 高橋 \\
\hline 高橋一男 & 高倉＼cjkstart耕一 & 高見 & 高梨＼cjkstart琢磨 & 高野俊一郎 & 高須賀圭三 & 高務 \\
\hline 竹田真木生 & 竹松＼cjkstart葉子 & 竹内 博昭 & 泰盛 & 田中 一裕 & 田中＼cjkstart幸一 & 良明 \\
\hline Tarpy, David R & 巽 えり子 & Terry, Irene & 土田 & 外川 & 所＜wide>雅彦 & 德丸 \\
\hline 富岡＼cjkstart憲治 & 外山 晶敏 & 上地＼cjkstart奈美 & 上野 & 上杉 & Vargo, Edward & 和智 \\
\hline 早苗 & Wajnberg, Eric & 渡邉 & 朋也 & 康彦 & 山田＼cjkstart佳廣 & 山本 \\
\hline 山村 光司 & Yaman, Mustafa & 山中 & 伸夫 & 矢野 & 屋良佳緒利 & 智秀 \\
\hline 横井＼cjkstart智之 & 萬屋＼cjkstart宏 & 吉賀＼cjkstart豊司 & 吉井 大志 & 正志 & Zhang, Honghai & \\
\hline
\end{tabular}

